Pobrane z czasopisma Annales N - Educatio Nova http://educatio.annales.umes.pl Data: 26/04/2023 16:10:27

DOI: 10.17951/en.2019.4.277-293

\begin{tabular}{lcr}
\hline & ANNALES \\
& & \\
UNIVERSITATIS MARIAE CURIE-SKŁODOWSKA & \\
LULLIN - POLONIA & SECTIO N & 2019 \\
\hline
\end{tabular}

Aneta Grodecka

Uniwersytet im. Adama Mickiewicza w Poznaniu

ORCID: http://orcid.org/0000-0003-3685-6911

grodecka@amu.edu.pl

\title{
O lekturze intuicyjnej w dobie neuronauki
}

\section{About Intuitive Interpretation in the Age of Neuroscience}

Streszczenie: Autorkę interesuje zakres modyfikacji szkolnej polonistyki przez odkrycia z zakresu neuronauki społecznej. Odwołując się do filozofii (Henriego Bergsona, Romana Ingardena, Francisco Vareli), najnowszych odkryć z zakresu neurologii, rozważa różnice pomiędzy „przeżywaniem” a „doświadczaniem”. Przywołano też wcześniejsze koncepcje dydaktyczne (Kazimierza Wóycickiego, Bronisława Poletura, Wincentego Okonia, Stanisława Bortnowskiego, Anny Janus-Sitarz) oraz wyniki eksperymentu związanego z intuicyjnym odbiorem wiersza Bolesława Leśmiana *** Wyszło z boru ślepawe, zjesieniate zmrocze... Na tej podstawie została nakreślona strategia lektury intuicyjnej opartej na fenomenologii, neuronauce i własnej praktyce nauczycielskiej.

Słowa kluczowe: dydaktyka polonistyczna; neuronauka; umysł; intuicja; interpretacja 
Dopóki jesteś w kleszczach schematu, dopóty nie jesteś w kontakcie z istotą rzeczy.

Czesław Dziekanowski ${ }^{1}$

\section{WPROWADZENIE}

Epoka wirtualna i doświadczenia właściwe dla XXI wieku, związane z nowymi technologiami, sprawiły, że takie kategorie, jak „uwaga”, „nastawienie” czy „wczucie” uległy semantycznej zmianie. Komputer zmodyfikował styl funkcjonowania poznawczego, wprowadził pojęcie programu obsługiwanego w sposób intuicyjny, dowartościował obieg reakcji mimowolnych i nieuświadomionych. Nowa mapa mózgu nie akcentuje jedynie - jak to miało miejsce wcześniej funkcji związanych z podziałem na półkule mózgowe, inaczej rozkłada punkty ciężkości, wiąże działanie umysłu z rozwojem ewolucyjnym. W myśl przywołanej przez neuronaukę $e^{2}$ koncepcji Paula MacLeana dysponujemy trzema mózgami: mózgiem gadzim, ssaków i nową korą, co zresztą odpowiada dawnemu podziałowi Arystotelesa na duszę wegetatywną, zwierzęcą i rozumną ${ }^{3}$. Mózg gadzi - pień mózgu - jest odpowiedzialny za wszystkie podstawowe funkcje przetrwania, głód, oddychanie, bicie serca, strach i „mordowanie z zimną krwią”. Mózg paleossaków - układ limbiczny - odpowiada za emocje oraz zachowania społeczne, uczucia przyjemności i przywiązania. Kora nowa, która dzieli się na płaty (potyliczny, czołowy), korę przedczołową i szarą materię, kojarzona jest z procesami poznawczymi i rozwiązywaniem problemów. Rozłożone w taki sposób funkcje i ich wzajemne relacje zmieniły sposób naszego myślenia o „myśleniu". Okazało się, że czynności związane z planowaniem i komunikacją są $\mathrm{w}$ równym stopniu rozwinięte u człowieka i u innych ssaków naczelnych (m.in. u delfinów). Nasze zachowanie jest wynikiem skomplikowanej, zintegrowanej pracy różnych struktur mózgu, podlega także oddziaływaniu szeregu reakcji

1 C. Dziekanowski, Intuicyjna prawda literatury [rozmowa z T. Olchanowskim], „ALBO albo. Inspiracje Jungowskie. Problemy Psychologii i Kultury” 2002, nr 4, s. 155.

$2 \mathrm{O}$ związkach neuronauki i humanistyki szerzej zob. A. Grodecka, Wstęp, [w:] Pisarze i mózg, „Poznańskie Studia Polonistyczne. Seria Literacka” 2018, nr 34, s. 7-15. O związkach neuronauki i dydaktyki, psychologii, pedagogiki zob. eadem, Dydaktyka polonistyczna w kontekstach neuronalnych, [w:] Edukacja polonistyczna. Metamorfozy kontekstów i metod, red. M. Karwatowska, L. Tymiakin, Lublin 2017, s. 121-135.

3 Na podstawie: W. Duch, Trzy mózgi. Notatki do wykładów, www.fizyka.umk.pl/ duch/Wyklady/Mozg/05-2-trzy_mozgi.htm [dostęp: 21.09.2017]. 
niekontrolowanych. Badania zmierzające do odkrycia mechanizmów „nieświadomego mózgu" kierują naszą uwagę w stronę intuicji.

Do sfery nieświadomości skutecznie zniechęcił nas Zygmunt Freud, który odkrył w umyśle sferę motywacji sprzecznych ze świadomym wyborem, stanowiących dla człowieka nieustanne źródło cierpień. W jego ujęciu nieświadomość była „gorąca i mokra, kipiąca pożądaniem i gniewem, miała charakter oniryczny, prymitywny i irracjonalny"4 . Carl G. Jung charakteryzował nieświadomość inaczej - wyróżnił jej odmianę osobistą i zbiorową; uznał, że te różne formy aktywności umysłu nie stanowią przeszkody na drodze do uzyskania stanu harmonii. Zróżnicował funkcje poznawcze, które według jego koncepcji obejmowały myślenie, uczucie, intuicję i percepcję, modyfikowane dodatkowo przez odmienne nastawienia do rzeczywistości: introwersję i ekstrawersję ${ }^{5} . \mathrm{Na}$ podstawie jego konstatacji można stworzyć nieograniczoną ilość kombinacji typów poznawczych (uzależnioną od tego, które nastawienie jest w umyśle dominujące). Nie wchodząc w szczegóły, trzeba podkreślić, że Jung nie wartościował wyróżnionych postaw, a poznanie intuicyjne i zmysłowe miało dla niego taką samą wagę. Wzmocniony zakres semantyczny intuicja zyskała w ramach fenomenologii. Roman Ingarden rozpoczął swoją drogę badawczą od filozofii Henriego Bergsona i jego rozumienia intuicji, poświęcając mu rozprawę doktorską, nad którą pracował w latach 1914-1917 pod opieką promotorską Edmunda Husserla. Odniósł się krytycznie do podstaw „filozofii życia”, według których to, co w człowieku duchowe i intelektualne, miało być sterowane przez głębsze, prelogiczne przeżywanie. Nie mógł zgodzić się z przekonaniem, że intuicja jest siłą, którą trzeba przeciwstawiać refleksji, że kontakt ze światem zapewnia nam tylko odczuwanie. Zakładał, że świadomość ma również swoją „substancję”, że można śledzić jej rozwój, a jeżeli chcemy dojść do pełnego poznania, musimy wiedzieć, co oglądaliśmy i uchwyciliśmy ${ }^{6}$. W jego ujęciu intuicja zyskała szerszy zakres - jej definicja obejmowała zarówno spostrzeżenia zewnętrzne (rzeczy i procesy realne), jak i wewnętrzne (cechy, stany i procesy psychiczne) ${ }^{7}$. Filozof nie akceptował poglądu, że świadome przeżycie jest rodzajem „funkcji mózgu". Uważał, że w jego czasach kwestie neurologiczne nie zostały jeszcze

4 L. Mlodinow, Nieświadomy mózg. Jak to, co dzieje się za progiem świadomości, wpływa na nasze życie, Warszawa 2016, s. 28.

5 Wykład na ten temat w: C.G. Jung, Typy psychologiczne, Warszawa 1997.

6 R. Ingarden, Intuicja i intelekt u Henryka Bergsona. Przedstawienie teorii i próba krytyki, [w:] idem, Z badań nad filozofia wspótczesna, Warszawa 1963, s. 123-143.

7 Szerzej zob. D. Mikeska-Kycia, Zagadnienie intuicji w filozofii Romana Ingardena, Kraków 2014. 
wyjaśnione w dostateczny sposób ${ }^{8}$. Wskazywał także, że analiza wyglądów rzeczy (spostrzeżenia zewnętrzne) nie ogranicza się do wyglądów wzrokowych, obejmuje bowiem też te dotykowe, słuchowe, a poza tym możemy mówić jeszcze o swoistych syntezach wyglądów9 . Rozwinięcie jego teorii, poszerzone o dane z zakresu neuronauki, zaproponował Francisco Varela. Stworzona w ten sposób neurofenomenologia zdecydowanie dowartościowuje poznanie intuicyjne. Okazuje się, że pomiędzy intuicją a rozumowaniem nie istnieje żadna sprzeczność, gdyż intuicja bez rozumowania jest ślepa, a pojęcia bez intuicji są puste ${ }^{10}$. Varela dowodzi, że poprzez zbliżenie się do fenomenu możemy odkryć prawdę. Obawia się jednak, że traktujemy nasze zdolności intuicyjne jako wrodzone i nie robimy zbyt wiele, aby je w sposób systematyczny rozwijać.

\section{INTUICJA W SYSTEMIE SZKOLNYM}

Polem bitwy, gdzie ważna staje się intuicja, jest akt interpretacji. Proces odbioru tekstu został w podstawie programowej podzielony na fazy: przeżycia, analizy i interpretacji oraz wartościowania. Mimo różnych wersji dokumentu nie gaśnie w nim fascynacja semiotyką, poszerzona o elementy hermeneutyki; w zapisach ciągle brakuje śladów fenomenologii. Semiotyka miała wprowadzić porządek i precyzję, a zaowocowała schematem interpretacji, który zabił w szkołach myślenie. Model hermeneutyczny, jak oceniła to Barbara Myrdzik ${ }^{11}$, miał być swoistym antidotum na mankamenty obowiązujących wcześniej modeli lektury. Okazało się, że postulowany dialog z tekstem oznacza w praktyce szkolnej poruszanie się w przestrzeni subiektywnych przeżyć, najczęściej utrzymanych w duchu introspekcji, których polonista nie potrafi okiełznać. W dokumentach oświatowych zaproponowano praktyczne rozwinięcia etapu ,rozpoznania” tekstu, jednak te zapisy bywają różnie odczytywane. Studenci specjalności nauczycielskiej rozumieją zapis „uczeń oddaje swoje wrażenia związane z dziełem" jako tożsamy z odpowiedzią na pytanie: Jak się wam utwór podobał? Studenci często mylą w praktyce interpretacyjnej

8 R. Ingarden, U podstaw teorii poznania. Czesść pierwsza, Warszawa 1971, s. 218-219. Na tej samej zasadzie filozof podważał paralelizm psychofizyczny, wzajemną zależność procesów fizjologicznych i poznawczych, dowodząc, że te fizyczne są ,dość tajemnicze i w swej naturze biochemicznej słabo rozpoznane w układzie nerwowym człowieka".

9 Idem, O dziele literackim. Badania z pogranicza ontologii, teorii języka i filozofii literatury, Warszawa 1988, s. 333.

10 F. Varela, Neurofenomenologia. Metodologiczne lekarstwo na trudny problem, „Avant” 2010, nr 1, s. 50.

11 B. Myrdzik, Rola hermeneutyki w edukacji polonistycznej, Lublin 1999. Wcześniejsze modele interpretacji to: utożsamianie przesłania tekstu z intencją autorską (odpowiedź na pytanie, co poeta miał na myśli), dominacja recepcji (rekonstrukcja genezy i sądów na temat utworu), analiza semiotyczna. 
sfery emocji i wrażeń zmysłowych, przeżyć i wartościowania. Nie ma w tym nic dziwnego i niewłaściwego - takiego kontaktu z dziełem ich nauczono, taką szkołę interpretacji zaliczyli. Odbiór tekstów sprowadzony do schematów, sprawdzany na poziomie testów, stał się karykaturą kontaktu z dziełem; „opunktowane” wypowiedzi na temat poezji, których wymagano najpierw na egzaminie gimnazjalnym, a potem na egzaminie maturalnym, skutecznie zniechęciły do innych działań interpretacyjnych. Nie zawsze tak było - ,przeżywanie” uchodziło za ważną kategorię w polskiej dydaktyce międzywojnia.

Kazimierz Wóycicki w podręczniku dla nauczycieli Rozbiór literacki w szkole (1921) sugerował, czerpiąc obserwacje z XIX-wiecznej dydaktyki i estetyki niemieckiej ${ }^{12}$, że ważne jest tzw. pierwsze czytanie ${ }^{13}$, które następuje przed analizą utworu. Wczesna faza kontaktu z tekstem miała zależeć od wielu czynników, zarówno tych związanych z miejscem, gdzie odbywa się lektura, jak i tych wynikających z predyspozycji osobowościowych (jak np. możliwości zrozumienia tekstu, bogactwo przeżyć, typ inteligencji, zdolność koncentrowania się na odbiorze). Bezpośrednie przeżycie tekstu stało się ważnym elementem strategii Bronisława Poletura (Interpretacja lektury w szkole jako środek kształcenia intuicji bezpośredniego przeżycia $i$ wyobraźni twórczej, 1924), który związał poetykę z myślą Bergsona i - powołując się na własną praktykę nauczycielską - dowodził, że analityczny rozbiór literacki niweczy przeżycia artystyczne i zabija zamiłowania czytelnicze. Zaproponował zestaw konkretnych rozwiązań służących kształceniu intuicji. Wśród nich znalazły się: symulacja (opracowanie utworów z punktu widzenia bohaterów z zachowaniem ich cech indywidualnych w zakresie światopoglądu, dykcji i mimiki), „wygłaszanie estetyczne” (wszelkie formy czytania tekstu, recytacji, deklamacji, inscenizacji), organizowanie procesów literackich (sąd nad bohaterem), wykresy graficzne akcji i napięcia emocjonalnego utworu, „konkursy rysunkowo-malarskie na ścisłość w oddaniu poetyckiego tekstu w języku linii i barw" ${ }^{\prime 14}$. W powojennym podręczniku Karola Lausza obie metody: impresyjna Wóycickiego i intuicyjna Poletura, mimo zawartych w nich ważnych postulatów dydaktycznych, zostały uznane za przestarzałe. Autor wskazał na praktyczne słabości tych strategii i uznał, że propagowanie intuicji ma niewiele wspólnego z właściwie

12 Badacz inspirował się pracami Otto von Greyerza oraz Maxa Dessoira. Zob. E. Kur, Pomoce obrazowe - refleksja Kazimierza Wóycickiego o roli sztuki wysokiej w dydaktyce polonistycznej (odczytanie we wspótczesnej perspektywie), [w:] eadem, Dydaktyka polonistyczna i jej konteksty, cz. 2: Sztuka - estetyka - kultura, Siedlce 2018, s. 78-79.

13 K. Wóycicki, Rozbiór literacki w szkole: podręcznik dla nauczycieli, [w:] Teoria kształcenia literackiego w latach 1918-1939. Antologia, red. L. Jazownik, cz. 1, Zielona Góra 2001, s, 23-24.

14 B. Poletur, Interpretacja lektury w szkole jako środek kształcenia intuicji bezpośredniego przeżycia i wyobraźni twórczej, „Ogniwo” 1924, nr 5/7, 8/9, 11, 12. 
pojętą ,psychologią materialistyczną" ${ }^{15}$. Do kategorii przeżycia powrócił Wincenty Okoń, kreśląc w Podstawach wyksztatcenia ogólnego $(1967)^{16}$ koncepcję wszechstronnego rozwoju umysłu ${ }^{17}$. Odwołał się on do pomysłów Erlebnispädagogik, ukształtowanych na przełomie XIX i XX wieku ${ }^{18}$, praktykowanych w szkołach niemieckich i francuskich. Zauważył, że „,przeżywanie” nie zostało precyzyjnie opisane; utożsamił je ze strategią emocjonalną, która miała stanowić przeciwwagę dla uczenia się przez przyswajanie, wymagała ona jednak regularnego kontaktu z dziełami sztuki. Przeżywanie nie miało zastąpić innych metod, ale oferowane rezultaty były nie do przecenienia. Strategia prowadziła do rozwoju empatii i umiejętności wyrażania ocen moralnych oraz wzmacniała chęć obcowania z kulturą, niwelując poczucie obojętności i zniechęcenia ${ }^{19}$.

Model „przeżywania” Okonia stał się ważnym elementem opracowań Henryki Kwiatkowskiej, która w artykule Rola przeżycia w kontakcie ucznia z dziełem literackim (1974) oraz w książce Przė̇ycie literackie a moralne postawy uczniów (1981) doprowadziła do zapaści tej kategorii, łącząc ją z czynnościami wartościowania i oceniania. Badaczka wprawdzie przywołała koncepcję Ingardena, jednak stworzyła dość pokrętną charakterystykę „przeżycia”. Uznała bowiem, że przeżywanie nie rozpoczyna się w momencie bezpośredniego kontaktu z dziełem, lecz dużo wcześniej. Ponadto podkreśliła jego jednostkowy charakter, niepokoił ją jednak sam efekt przeżycia - uformowanie niematerialnego przedmiotu w umyśle odbiorcy. Stwierdziła, że warstwa znaczeniowa jest ważnym składnikiem przeżywania, przeżycie nigdy nie powstaje irracjonalnie ${ }^{20}$, a przeżycie estetyczne jest czymś w rodzaju „przeżycia rozumiejącego"21. Badaczka postępowała w zgodzie z wykładnią ówczesnej psychologii. Nie potrafiła zaakceptować faktu, że uczucia rodzą się spontanicznie i nie można ich kontrolować. Jej stanowisko było zbieżne z filozofią marksistowską, według której o wartości dzieła sztuki (w tym dzieła

15 K. Lausz, Metoda intuicyjna (intuitywna), metoda impresyjna, [w:] idem, Podstawowe problemy współczesnej metodyki literatury, Warszawa 1970, s. 227-233.

16 W. Okoń, Podstawy wykształcenia ogólnego, Warszawa 1976.

17 Okoń przywołuje XIX-wieczną psychologię Johanna Friedricha Herbarta, według której w umyśle człowieka funkcjonują niepodzielne „sploty wyobrażeń” oraz wyobrażenia „niesplecione”, oczekujące na włączenie do całości nazywanych „,masami apercepcyjnymi”.

18 Chodziło o „pedagogikę przeżywania” (Erlebnispädagogik), stworzoną na początku XX wieku przez Fritza Gansberga i Heinricha Scharrelmanna. Według ówczesnych koncepcji przeżycie miało pobudzać u ucznia zdolność kojarzenia, było możliwe dzięki budowaniu więzi między uczniem a nauczycielem.

19 W. Okoń, op. cit., s. 86-89.

20 H. Kwiatkowska, Rola przeżycia w kontakcie ucznia z dziełem literackim, [w:] Nowoczesne tendencje w dydaktyce literatury i języka polskiego, red. W. Paterniak, Warszawa 1974, s. 163.

21 Ibidem, s. 150-151. 
literackiego) miały decydować wartości w nim prezentowane, a stąd już blisko było do praktyki manipulowania przeżyciami prowadzącej do uzyskania określonego celu edukacyjnego.

Inne zasady związano z przeżyciem w ramach dydaktyki zwróconej w stronę haseł integracji sztuk. Wśród przykładów wypada wymienić monografię Jana Cofalika (1961), tom Polonistyka zintegrowana (2000) oraz pisma dydaktyczne Stanisława Bortnowskiego $(1974,1991)$. Ważny okazał się sam nauczyciel oraz sposób, w jaki przeżywa dzieła sztuki, a także to, jak przekazuje swe przeżycia innym: „Przeżycie to znajduje wyraz nie tylko w sugestywnym tłumaczeniu dzieła, ale również w tym, co jest zewnętrznym, cielesnym odpowiednikiem stanów duchowych: w geście, ruchu, głosie, spojrzeniu"22. Uznano, że polonista, który jest amatorem w sferze sztuk plastycznych, jest zdolny organizować wartościowe i cenne poznawczo lekcje oparte na przeżywaniu, a brak wiedzy specjalistycznej wyzwala ,świeżość, bezpośredniość i naturalność w kontaktach ze sztuką"²3. Te obserwacje okazały się zbieżne z założeniami neurodydaktyki i potwierdzają dość oczywistą z punktu widzenia praktyki nauczycielskiej - następującą tezę Manfreda Spitzera: „,...] tylko ktoś, kto jest zafascynowany swoim przedmiotem, będzie w stanie właściwie go nauczać"24. Problem przeżywania tekstów stał się ważnym zagadnieniem metodyki Bortnowskiego, który zabiegał o czytanie intuicyjne i impresyjne, przywołując dawne tezy Wóycickiego ${ }^{25}$. Badacz poszukiwał trafnych pytań otwierających tekst przed czytelnikiem, balansował między metodologiami, dostrzegał również - co ważne - niebezpieczeństwa związane z aktem przeżywania. Wiedział, jak banalna może być odpowiedź czytelnika na lakoniczne sygnały pozostawione przez pisarza: „[...] wystarczy zastanowić się nad własnymi możliwościami w określaniu przeżyć towarzyszących nam podczas czytania nieznanej książki, oglądania wystawy plastycznej bądź słuchania koncertu, by z zażenowaniem dojść do wniosku, że i my jesteśmy bezradni”’26.

Przeżycie tekstu, podbudowane hermeneutyką, stało się elementem jednego z modeli czytania opracowanych przez Annę Janus-Sitarz. Związano je z zestawem potencjalnych zadań przeznaczonych dla ucznia-czytelnika, wśród których znalazły się pytania: O czym jest tekst? Czego nie rozumiesz? Co tekst mówi do

22 J. Cofalik, Malarstwo i muzyka w nauczaniu języka polskiego, Katowice 1961, s. 65.

23 D. Karkut, Malarskie inspiracje lekcji polonistycznych, [w:] Polonistyka zintegrowana, red. K. Ożóg, J. Pasterska, Rzeszów 2000, s. 124.

24 M. Spitzer, Jak uczy się mózg, Warszawa 2017, s. 145.

25 S. Bortnowski, Ku czytaniu intuicyjnemu i impresyjnemu, [w:] idem, Jak uczyć poezji?, Warszawa 1991.

26 Idem, Młodzież a lektury szkolne, Warszawa 1974, s. 7. 
ciebie? Czy tekst mówi coś o tobie? ${ }^{27}$ Tak organizowana faza „przeżywania” miała stanowić wstęp do działań analitycznych, prowadzonych w zupełnie innym duchu (interpretacja kontekstowa). Współczesne odkrycia w sferze umysłu prowadzą do rewizji stworzonych dotychczas koncepcji dydaktycznych. Umysł jest fenomenem emergentnym. Okazuje się, że intuicji nie można dłużej lekceważyć, a reakcji odbiorczych nie można opisywać za pomocą „faz” czy „modeli”.

\section{STRATEGIA INTUICYJNA}

Intuicję można lokować w różnych systemach filozoficznych (Bergson, Jung, Ingarden), jednak warto pamiętać, że jeśli nie uwzględnimy motywacji neuronaukowej, to intuicja przywołuje strategię „odczuwania sztuki”, która ma dość staroświecki i sentymentalny sens. Koncepcja „wczucia się” w dzieło i intencje twórcy, wykreowana przez Theodora Lippsa, zaowocowała w XIX wieku szeregiem koszmarnych świadectw krytyki impresyjnej. Myśląc o zastosowaniu intuicji w praktyce, trzeba uporządkować siatkę pojęć, gdyż w obrębie dokumentów oświatowych i dydaktycznych koncepcji często dochodzi do pomieszania takich pojęć, jak: przeżycie, doświadczenie, przeżycie literackie, przeżycie estetyczne ${ }^{28}$. W tab. 1 i 2 został przedstawiony zakres semantyczny tych terminów.

Tab. 1. Przeżycie a doświadczenie

\begin{tabular}{|l|l|}
\hline Przeżycie - Durchleben (akty świadomości) & $\begin{array}{l}\text { Doświadczenie - Erleben (doświadczenie } \\
\text { bezpośrednie) }\end{array}$ \\
\hline $\begin{array}{l}\text { Przeżycie, związane z hermeneutyką, wspar- } \\
\text { te jest na percepcji z mysłowej, zdeter- } \\
\text { minowanej przez aktualny stan przekonań } \\
\text { motywujących: celowych dążeń i pragnień } \\
\text { (podstawy intencjonalne) }\end{array}$ & $\begin{array}{l}\text { Doświadczenie, związane z empiryzmem, } \\
\text { wsparte jest na percepcji z mysłowej, rozu- } \\
\text { mianej jako bierna odbiorczość zdominowana } \\
\text { przez bodźce fizyczne i procesy fizjologiczne } \\
\text { (podstawa jednoznacznie nieintencjonalna) }\end{array}$ \\
\hline Koncentracja na podmiocie & Koncentracja na pr zedmiocie \\
\hline Interpretacja & Wyjaśnienie naukowe \\
\hline
\end{tabular}

Źródło: opracowanie własne na podstawie: R. Ingarden, Dążenia fenomenologów (1919), [w:] idem, Z badań nad filozofia współczesną, Warszawa 1963; W. Tatarkiewicz, Skupienie i marzenie. Studia z zakresu estetyki, Kraków 1951; W. Tatarkiewicz, Przeżycie estetyczne, [w:] idem, Dzieje sześciu pojęć, Warszawa 1975; N. Leśniewski, Hermeneutyka przeżycia, „Teksty Drugie” 2007, nr 1/2.

27 A. Janus-Sitarz, Wolność i etyka czytania hermeneuty, [w:] eadem, Przyjemność i odpowiedzialność w lekturze. O praktykach czytania literatury w szkole. Konstatacje, oceny, propozycje, Kraków 2009, s. 145.

28 Władysław Tatarkiewicz stworzył własną klasyfikację przeżyć estetycznych, dzieląc je na „skupienie”, w pełni skoncentrowane na dziele sztuki, nazywane kontemplacją estetyczną, oraz „marzenie”, w którym stan koncentracji nie występuje. 
Tab. 2. Przeżycie literackie a przeżycie estetyczne

\begin{tabular}{|l|l|}
\hline Przeżycie literackie & Przeżycie estetyczne \\
\hline $\begin{array}{l}\text { Ma charakter osobisty, jego tkanką są } \\
\text { skojarzenia i pamięć; polega na po- } \\
\text { szukiwaniu sensu słów, które niekiedy } \\
\text { przyjmują postać obrazów pojawiających } \\
\text { się w wyobraźni }\end{array}$ & $\begin{array}{l}\text { Zmienia się w zależności od tego, czy mamy do } \\
\text { czynienia z malarstwem, architekturą czy muzyką. } \\
\text { Zostaje wyzwolone przez przedmiot zmysłowy, } \\
\text { jego jakość mniej zależy od intelektu, a bardziej od } \\
\text { predyspozycji zmysłowych (możliwości w zakresie } \\
\text { patrzenia, dotykania czy słuchania) }\end{array}$ \\
\hline Myślenie & Percepcja \\
\hline Koncentracja na podmiocie & Koncentracja na przedmiocie \\
\hline
\end{tabular}

Źródło: opracowanie własne na podstawie: R. Ingarden, Dążenia fenomenologów (1919), [w:] idem, Z badań nad filozofia wspótczesna, Warszawa 1963; W. Tatarkiewicz, Skupienie i marzenie. Studia z zakresu estetyki, Kraków 1951; W. Tatarkiewicz, Przeżycie estetyczne, [w:] idem, Dzieje sześciu pojęć, Warszawa 1975; N. Leśniewski, Hermeneutyka przeżycia, „Teksty Drugie” 2007, nr 1/2.

Obie strategie - przeżycie i doświadczenie - oparte są, co może być mylące, na zmysłach, przypisują im jednak różną wartość poznawczą. „Przeżycie” i „przeżycie literackie” związane są z koncentracją na podmiocie, a „doświadczenie estetyczne" i „przeżycie estetyczne” - z koncentracją na przedmiocie. Ta zbieżność jest zastanawiająca. Budzi ona skojarzenie z metaforami odbioru wprowadzonymi do obiegu kultury europejskiej przez Meyera H. Abramsa, które stosuje się w badaniach sztuki ${ }^{29}$. Koncentracji na podmiocie odpowiada metafora „reflektora” (odbiorca, który uosabia doznania hermeneutyczne, jego konkretyzacje cechuje swoboda i wielość), natomiast koncentracji na przedmiocie - metafora „lustra” (odbiorca, który postępuje zgodnie z tekstem, może być formalistą, lecz także wrażeniowcem). W opisach świadomości percepcyjnej drugiej połowy XX wieku stosowano podobne semantycznie określenia ${ }^{30}$ : „odbiorca negocjator" (wnosi do tekstu własne przeżycia, interpretuje własne emocje wzbudzone przez dzieło) i „odbiorca jako strona dialogu” (daje się dziełu porwać, wchłonąć lub wessać). Gdy założyć powrót do fenomenologii, co postuluję w niniejszym artykule, ważna jest reaktywacja „doświadczenia”31 - strategii odbiorczej „lustra”,

29 Kategorie opisane w pracy Abramsa pt. Zwierciadlo i lampa. Romantyczna teoria poezji a tradycja krytycznoliteracka (Gdańsk 2003) stosowała w opisie recepcji potocznej Anna Matuchniak-Krasuska (Publiczność wobec metafory plastycznej. O recepcji groteski Jerzego Dudy-Gracza, Łódź 1999).

30 Opisuje je Zofia Rosińska (Tożsamość odbiorcy. Psychoanalityczne punkty widzenia, [w:] Twórczy odbiór sztuki, red. J. Brach-Czaina, Białystok 1992), powołując się na określenia zapożyczone z książek Ernsta Krisa i Andre Greena.

31 Literaturoznawstwo odpowiedziało twierdząco na pytanie, czy można za pomocą literatury mierzyć doświadczenie. Wcześniej utwór literacki, zdominowany przez doktrynę niewyrażalnego, zwyczajowo nie był ujmowany w kontekście poznania - był raczej traktowany jako rodzaj medium, które przesłania prawdziwą rzeczywistość i nie dotyczy jej w bezpośredni sposób. Badania o charakterze antropologicznym dowartościowały doświadczenie (Ryszard Nycz, Magdalena Rem- 
gdy odbiorca funkcjonuje jako strona dialogu, formalista, wrażeniowiec, intuicjonista. Zakładam, że przeżywanie literatury nie może pomijać jej bezpośredniego doświadczania, a w kształtowaniu strategii odbioru literackiego można się posiłkować elementami przeżycia estetycznego. Nie trzeba czytać obrazów, aby je doświadczać i przeżywać; trzeba czytać literaturę i jej doświadczać, a nie jedynie ją przeżywać. Do polonisty należy stworzenie odpowiednich warunków, by dochodziło na jego lekcjach do „smakowania” literatury i sztuki.

\section{W STRONE PRAKTYKI}

Przemyśleń na temat intuicji w praktyce szkolnej dostarcza badanie ${ }^{32}$, jakie przeprowadzono $\mathrm{w}$ grupach uczniów gimnazjum i studentów polonistyki na temat odbioru wiersza Bolesława Leśmiana *** Wyszło z boru ślepawe, zjesieniałe zmrocze ze zbioru Łąka. To wiersz trudny w interpretacji, bo zamknięty wobec tradycyjnej eksplikacji, mający swoje stałe miejsce w szkolnym obiegu ${ }^{33}$. Przynależy on do cyklu poetyckiego, gdzie silne są napięcia pomiędzy światem ludzkim a naturą, a przyroda przybiera niepojętą i fantastyczną formę ${ }^{34}$. Bohaterem lirycznym wiersza jest zmrocze - istota, która wyłania się z magicznego świata ${ }^{35}$, budząc strach i odrazę. Neologizm zmrocze przywołuje doznania ciemności i rozproszonego, nikłego światła, przestrzeni, w której rozgrywa się gra cieni, kolory tracą nasycenie i wszystko przybiera szary kolor ${ }^{36}$. Epitet $z j e s i e n i a ł e$

bowska-Płuciennik). Ta tendencja żywa jest także w nauce o sztuce (Juhani Pallasmaa, Thomas Elsaesser, Malte Hagener, Marek Henrykowski).

32 Badania przeprowadziła w 2017 roku w ramach pracy magisterskiej studentka polonistyki w klasach drugich gimnazjum oraz w grupach studentów II roku licencjatu filologii polskiej. Wypowiedzi uczestników badania pochodzą z pracy: M. Sobańska, Apollo i Psyche w edukacji polonistycznej. W kręgu badań nad umystem i intuicja, Poznań 2018 (praca magisterska napisana pod kierunkiem prof. Anety Grodeckiej). Wykorzystuję materiał zebrany przez studentkę, ale interpretuję go z własnej perspektywy badawczej.

33 W podręczniku Małgorzaty Chmiel, Wilgi Hermana, Zofii Pomirskiej i Piotra Doroszewskiego pt. Słowa na czasie. Podręcznik do kształcenia literackiego i kulturowego dla klasy trzeciej gimnazjum (Warszawa 2010) lektura wiersza prowadzi do przekładu intersemiotycznego: „Wykonaj ilustrację, która zobrazuje Twoją wizję zjesieniałego zmrocza. Zastosuj technikę collage" (s. 23).

34 M. Kokoszka, Poeta-żuk zielony, czyli o Leśmianowskim mikroświecie, [w:] Zaczytani. Tom jubileuszowy dla Profesor Anny Węgrzyniak, red. M. Bernacki, T. Bielak, I. Gielata, K. Koziołek, Bielsko-Biała 2012, s. 155.

35 M. Głowiński, Zaświat przedstawiony, [w:] idem, Zaświat przedstawiony. Szkice o poezji Bolesława Leśmiana, Kraków 1998, s. 296. Badacz opisuje ruch między światami w poezji Leśmiana jako wędrówkę ze świata realnego do światów fantastycznych.

36 A. Czabanowska-Wróbel, „Niepojętność zieloności” i „,możliwość szkarlatu”. O kolorystyce Bolesława Leśmiana, [w:] eadem, Złotnik i śpiewak. Poezja Leopolda Staffa i Bolestawa Leśmiana w kręgu modernizmu, Kraków 2009, s. 293. 
(utworzony od wyrazu jesiennieć) ${ }^{37}$ sugeruje porę roku. Zmrocze ma uszkodzony wzrok, posługuje się instynktem, jego cielsko jest kostropate, co oznacza zbitkę wrażeń szorstkie i chropowate; pokrywa je dziwna substancja zostawiająca wszędzie ślady; może oswoić je kontakt z „białą dłonią”. Obrazowość wiersza jest wzmocniona sensualnie, obejmuje rozbudowany zestaw taktylnych wrażeń, budzi silne emocje i zawiera symboliczną scenę, przez co wyzwala wieloraką interpretację. Tekst Leśmiana został zaprezentowany uczestnikom badania bez podawania informacji o autorze, tytule i dacie powstania. Zastosowano strategię „skupienia na doświadczeniu” zaproponowaną przez Berniego Nevillego, opartą na kilku etapach ${ }^{38}$ :

1. Przed zapoznaniem się z utworem badani zamykali oczy, wyciszali emocje i relaksowali się.

2. Czytali po cichu tekst i starali się przenieść na poziom, na którym odbierają emocje; mieli koncentrować się na odczuciach, które wywołała w nich pierwsza lektura. Zapisywali te emocje (mogli pisać lub rysować).

3. Następnie podejmowali próbę wytworzenia w umyśle obrazu, który pierwsze emocje wywołały w ich podświadomości. Ich zadaniem było naprzemienne koncentrowanie się na obrazie i na emocjach, błądzenie myślami od jednego stanu do drugiego.

4. Konfrontacja doznań kończyła się w momencie, gdy obie formy składały się w umyśle w spójne doznanie. Wtedy uczestnicy badania przywoływali ten ostateczny obraz i zapisywali go, szukając słów, które mogą go odzwierciedlać.

Prowadząca badanie zebrała 49 różnych świadectw odbioru wiersza (22 prace uczniowskie i 27 prac studenckich). Dwóch respondentów (z grupy studenckiej) nie wyraziło chęci, by uczestniczyć w takim zadaniu: Nie poczułem emocji; Brak wrażenia, rozpraszaty mnie samochody, nie nadaję się do tej metody, nie dziataja na mnie tego typu zadania. Uczucie: zmieszanie, zakłopotanie; połączenie: niezrozumienie; obraz: pomieszanie z poplątaniem elementów wiersza.

Okazało się, że wiersz Leśmiana wywołał na poziomie odbioru podobne obrazy i emocje w dwóch różnych wiekowo grupach. Jedyna różnica wystąpiła w czasie tworzenia obrazów w grupie studenckiej, gdy badani przywoływali dość zaskakujące, niezgodne z semantyką tekstu skojarzenia z wojenną apokalipsą, złotą pszczołą, barokową martwą naturą. Sfera emocji wyzwolonych podczas

37 Hasło: jesiennieć, [w:] Stownik języka polskiego PWN, https://sjp.pwn.pl/szukaj/jesiennie\%C4\%87.html [dostęp: 18.02.2019].

38 B. Neville, Psyche i edukacja. Emocje, wyobraźnia i nieświadomość w uczeniu się i nauczaniu, Kraków 2009, s. 137-138. 
lektury zawierała wszystkie elementy podstawowej palety Paula Ekmana ${ }^{39}$. Odnotowano odczucia skrajne, takie jak: smutek (10 prac), strach (9), obrzydzenie (3), niepewność, niepokój, lęk (12). Na etapie kształtowania obrazu odnotowano: zdziwienie i zaciekawienie (7), nostalgię i spokój (2), a nawet radość (4). Na poziomie konkretyzacji świata przedstawionego i bohatera lirycznego badani byli zgodni. Sceneria wiersza wywoływała negatywne określenia związane z brzydotą i rozpadem („świat grozy”, „świat z krwi”), doznania ciemności, mroku i chłodu, skojarzenia z mgłą, łąką, lasem i bagnem. Badani tworzyli różne konkretyzacje bohatera lirycznego - najczęściej traktowali go jako „zwierzę”. Proponowane określenia: wąż, ośmiornica, pszczoła, kot, potwór, istota, stwór, dziwadto, zwierze zabójcze i dzikie, cud natury, zwierzę zagubione, odczuwajace strach, szczęśliwe. Ciekawe są świadectwa obioru, które zawierają rozbudowane opisy i narracje:

Czuję smutek i dociekliwość, niewiedzę, czego dotykam. Czuję dotyk zwierzęcia, lecz nie wiem, jakiego. To ja decyduję, co mógłby zrobić, czy go dotknać czy tylko obserwować. Widziatam dziwnego kota, który zachowywat sięnienaturalnie. Czuje jakaś tajemnice, sekret. [gimnazjalistka, klasa 2].

Ciemny, wysoki las iglasty, z którego wytania się kosmaty potwór, Wychodzi na pole. Czuję lęk przed nim. Ma złe oczy. Chce się do mnie zblizyć, a ja chcę uciekać. Stoje w pewnym oddaleniu od linii drzew. Obawa, niepewność, chęć ucieczki. [studentka, II rok licencjatu]

Prace potwierdzają, że badani przyjmowali różne linie interpretacyjne. Według jednej wykładni wiersz opisuje konflikt świata ludzi i natury, wyraża myśl, że człowiek zawłaszcza świat przyrody dla własnych celów. Inna interpretacja zaś wskazuje, że stanowi on pochwałę uczuć, jest świadectwem poszukiwania miłości, wyrazem dążenia do spokoju i harmonii. Niektórzy uczestnicy badania (głównie w grupie studenckiej) wiązali z tekstem refleksje egzystencjalne, sformułowali wykładnię o ulotności ludzkiego życia i narzucaniu jednostce Gombrowiczowskiej formy.

Wiersz Leśmiana wprowadził czytelników w różne stany umysłu. U niektórych uruchomił sferę własnych odczuć i problemów, co oddaliło ich od tekstu. Te przypadki odsłaniają słabość zastosowanej metody. Podobnie trzeba potraktować wyzwolenie mechanizmu kulturowych skojarzeń (m.in. przywoływane

39 Ekman wyróżnił sześć podstawowych emocji: radość, zaskoczenie, złość, smutek, strach i wstręt. 
przez studentów odwołania do wojennej apokalipsy) - te spontaniczne próby interpretacji kontekstowej nie pomogły w rozumieniu (studentom zabrakło odpowiednich kompetencji). Metoda intuicyjna okazała się owocna, gdy uczestnicy badania wchodzili w „rolę lustra”, co szczególnie widać w odbiorze wrażeń taktylnych (te dominowały w wielu relacjach). Za inną zaletę metody można uznać fakt wyzwolenia tożsamości narracyjnej, co było widoczne w pracach, których autorzy nie rysowali, nie wyliczali emocji po przecinku, lecz opisywali swe doświadczanie w narracyjnej formie. Badanie dotyczące użyteczności intuicji odsłoniło skomplikowaną przestrzeń odbioru - sferę, w której mieszczą się: niekontrolowany akt przeżywania, swoboda kulturowych skojarzeń, zróżnicowana paleta emocji i moment doświadczania tekstu. Wyzwolenie intuicji odbiorczej pozwoliło zbliżyć się do szarego i taktylnego świata Leśmiana, do strategii, którą stosują dobrzy ilustratorzy poezji. Okazało się, że metoda intuicyjna sytuuje się blisko aktywności odbiorczej związanej z przekładem intersemiotycznym, a pomysły uczestników badania mieszczą się w ramach przekładalności.

\section{ZAKOŃCZENIE}

Neville, oceniając stan współczesnej edukacji, zauważył, że za bardzo zawierzyliśmy Apollinowi - strategii opartej na przejrzystości intelektu, a zarazem zapomnieliśmy o Psyche - młodej dziewczynie ze skrzydłami motyla, uosobieniu ludzkiej duszy, odpowiadającej za „szósty zmysł”. Wypada zgodzić się z jego obserwacją:

Współczesne społeczeństwa bardziej cenią poznanie empiryczne (a więc zmysłowe) niż intuicyjne [podkr. - A.G.]. Rozwój społeczeństwa przemysłowego i nierozerwalnie związanej z nim biurokracji stwarza zapotrzebowanie na ludzi o dobrze rozwiniętych zmysłach. Tacy właśnie ludzie zaprojektowali i kontrolują szkolnictwo, w którym dzieci uczone są zapamiętywania faktów, wyciągania wniosków na podstawie niezbitych dowodów, manipulowania cyframi i słowami, posługiwania się skomplikowanymi urządzeniami ${ }^{41}$.

Ucznia-intuicjonistę czeka w szkole ciężki żywot; może zniechęcić go proste nauczycielskie polecenie „powiedziałeś, a teraz to uzasadnij”, bo gdy milczy, jego

40 W związku z odkryciem zmysłu równowagi synonimem intuicji stał się „siódmy zmysł”. Por. M. Zawistowska, Szósty zmyst, [w:] Sensualność w kulturze polskiej, http://sensualnosc.bn.org. pl/pl/articles/szosty-zmysl-698 [dostęp: 28.09.2019].

41 B. Neville, op. cit., s. 184-185. 
milczenie uznawane jest za akt niewiedzy. Budzą się wątpliwości. Czy nasze zmysły mogą być wolne, czy zawsze są zaangażowane i służą ważnym celom? Czy kresem naszych dążeń jest rozwój intelektu? Gdzie w systemie wartości lokuje się samowiedza? Czy odbiór intuicyjny został już skutecznie wyrugowany z edukacji przez inne modele obowiązujące w procesie kształcenia?

Rozwojowi intuicji nie sprzyjają współczesne koncepcje dydaktyczne. Po wojnie przywoływano do porządku nauczycieli, by skupiali się na przekazywaniu wiedzy poprawnej ideologicznie, a metoda przyswajania informacji, stanowiąca domenę myśli marksistowskiej, była obowiązującym modelem nauczania. Współcześnie popularne stały się takie kierunki, jak: nauczanie poprzez praktyczne działanie, wyzwalanie sfery przeżyć związanych z dziełem oraz nauczanie ku wartościom. Z niepokojem obserwuję, jak nauczanie aksjologiczne utożsamia się z nauczaniem podporządkowanym ideologii, jak samowiedza i rozwój umysłu milkną w ramach dydaktyki zorientowanej zarówno patriotycznie, jak i liberalnie ${ }^{42}$. Jakie znaczenie przypisuję intuicji w ramach edukacji? Uruchamia ona aktualną wiedzę o umyśle i pozwala docenić tkwiące w nim zróżnicowanie. Władze umysłu lub - jak nazywał je Ingarden - „władze psychiczne” (pamięć, władze sądzenia, myślenia, chcenia) wykraczają poza świadomość i sprawiają, że ludzie odznaczają się „rozmaitą wrażliwością na pewne dane doświadczenia (mieć zamkniętą lub otwartą drogę do pewnych danych i związków między nimi)" ${ }^{\text {"3 }}$. Intuicja zmienia sposób odbioru tekstów, lektura intuicyjna bliska jest zasadom przekładu intersemiotycznego; sprawia, że odbiór tekstów staje się bardziej twórczy, oraz - co uznaję za istotne - ocala potencjał terapeutyczny ukryty w literaturze i sztuce. Intuicja pozwala wiązać estetykę i samowiedzę. To nie jedyna wartość płynąca z zastosowania fenomenologii. Ingarden uważał, że analiza fenomenologiczna jest „zdolna obudzić w nas potrzebę bezpośredniego obcowania z rzeczywistością, zwłaszcza rzeczywistością człowieka, i może odsłonić przed naszymi oczyma całe bogactwo tej rzeczywistości, i pozwolić na jej ukochanie" ${ }^{44}$.

Czy takie argumenty przekonają polonistów? Neuronauka zmienia nasze wyobrażenia o źródłach kreatywności, sytuuje myślenie na różnych poziomach: świadomym (celowym) oraz nieświadomym (automatycznym) ${ }^{45}$, ale zapewne

42 Pewne nadzieje można wiązać z dydaktyką empatyczną przy założeniu, że nie oznacza ona strategii dominującej, iż impuls empatyczny wyzwalają tylko wybrane teksty kultury.

43 R. Ingarden, U podstaw teorii poznania, cz. 1, Warszawa 1971, s. 262.

44 Ibidem, s. 379.

45 Ten nieświadomy umysł bywa nazywany „głęboką aktywacją kognitywną”, „myśleniem oszczędnościowym" (oznacza jedną czwartą wysiłku wkładanego w normalne myślenie). Odkrycie impulsów nieświadomych zaowocowało koncepcją Seymoura Epsteina, który podzielił wiedzę na 
daleko stąd do zmian w sposobach kształcenia, gdyż te podlegają innym mechanizmom. Nauczyciele wiedzą, że intuicji nie da się zmierzyć, nie podlega ona ewaluacji, ,jest niewidoczna”, w związku z tym nie czują potrzeby, by zajmować się mechanizmami „szybkiego myślenia”. Najtrudniejsze w praktyce może okazać się różnicowanie postaw. Stosowanie strategii intuicyjnej wymaga dowartościowania intuicjonistów, a w szkole trudno zerwać z zasadą percepcyjnej demokracji. Wielu nauczycieli, choć umiejętności metakognitywne uchodzą za efekt pożądany, może odbierać takie działanie jako niepedagogiczne. Zapewne czas zerwać z oświeceniowym racjonalizmem, nie szukać już natchnienia w postmodernizmie czy wytchnienia w aksjologii. Gdy przełożymy intuicję na jednostki dające się komunikować, uznamy, że niewiedzenie jest stanem umysłu, a wychodzenie poza schematy - ważnym celem edukacyjnym, wtedy w pewien sposób zbliżymy się do naszej nowoczesności.

\section{BIBLIOGRAFIA}

Abrams M.H., Zwierciadto i lampa. Romantyczna teoria poezji a tradycja krytycznoliteracka, Gdańsk 2003.

Bortnowski S., Ки czytaniu intuicyjnemu i impresyjnemu, [w:] idem, Jak uczyć poezji?, Warszawa 1991.

Bortnowski S., Mtodzież a lektury szkolne, Warszawa 1974.

Chmiel M., Herman W., Pomirska Z., Doroszewski P., Stowa na czasie. Podręcznik do kształcenia literackiego i kulturowego dla klasy trzeciej gimnazjum, Warszawa 2010.

Cofalik J., Malarstwo i muzyka w nauczaniu języka polskiego, Katowice 1961.

Czabanowska-Wróbel A., „Niepojętność zieloności” i „możliwość szkartatu”. O kolorystyce Bolestawa Leśmiana, [w:] eadem, Złotnik i śpiewak. Poezja Leopolda Staffa i Bolestawa Leśmiana w kręgu modernizmu, Kraków 2009.

Duch W., Trzy mózgi. Notatki do wykładów, www.fizyka.umk.pl/ duch/Wyklady/ Mozg/05-2-trzy_mozgi.htm [dostęp: 21.09.2017].

Dziekanowski C., Intuicyjna prawda literatury [rozmowa z T. Olchanowskim], „ALBO albo. Inspiracje Jungowskie. Problemy Psychologii i Kultury" 2002, nr 4.

Głowiński M., Zaświat przedstawiony, [w:] idem, Zaświat przedstawiony. Szkice o poezji Bolestawa Leśmiana, Kraków 1998.

Grodecka A., Dydaktyka polonistyczna w kontekstach neuronalnych, [w:] Edukacja polonistyczna. Metamorfozy kontekstów i metod, red. M. Karwatowska, L. Tymiakin, Lublin 2017.

Grodecka A., Wstęp, [w:] Pisarze i mózg, „Poznańskie Studia Polonistyczne. Seria Literacka" 2018, nr 34.

doświadczalną, niewerbalną i intuicyjną oraz racjonalną, analityczną i werbalną. Zob. D. Meyers, Dwa rodzaje wiedzy, [w:] idem, Intuicja - jej siła i stabość, Taszów 2004, s. 53-55. 
Hasło: jesiennieć, [w:] Stownik języka polskiego PWN, https://sjp.pwn.pl/szukaj/jesiennie\%C4\%87.html [dostęp: 18.02.2019].

Ingarden R., Dążenia fenomenologów (1919), [w:] idem, Z badań nad filozofia wspótczesna, Warszawa 1963.

Ingarden R., Intuicja i intelekt u Henryka Bergsona. Przedstawienie teorii i próba krytyki, [w:] idem, Z badań nad filozofia wspótczesna, Warszawa 1963.

Ingarden R., O dziele literackim. Badania z pogranicza ontologii, teorii języka i filozofii literatury, Warszawa 1988.

Ingarden R., U podstaw teorii poznania, cz. 1, Warszawa 1971.

Janus-Sitarz A., Wolność i etyka czytania hermeneuty, [w:] eadem, Przyjemność i odpowiedzialność w lekturze. O praktykach czytania literatury w szkole. Konstatacje, oceny, propozycje, Kraków 2009.

Jung C.G., Typy psychologiczne, Warszawa 1997.

Karkut D., Malarskie inspiracje lekcji polonistycznych, [w:] Polonistyka zintegrowana, red. K. Ożóg, J. Pasterska, Rzeszów 2000.

Kokoszka M., Poeta-żuk zielony, czyli o Leśmianowskim mikroświecie, [w:] Zaczytani. Tom jubileuszowy dla Profesor Anny Wegrzyniak, red. M. Bernacki, T. Bielak, I. Gielata, K. Koziołek, Bielsko-Biała 2012.

Kur E., Pomoce obrazowe - refleksja Kazimierza Wóycickiego o roli sztuki wysokiej $w$ dydaktyce polonistycznej (odczytanie we wspótczesnej perspektywie), [w:] eadem, Dydaktyka polonistyczna i jej konteksty, cz. 2: Sztuka - estetyka - kultura, Siedlce 2018.

Kwiatkowska H., Przeżycie literackie a moralne postawy uczniów, Warszawa 1981.

Kwiatkowska H., Rola przeżycia w kontakcie ucznia z dziełem literackim, [w:] Nowoczesne tendencje $w$ dydaktyce literatury $i$ języka polskiego, red. W. Paterniak, Warszawa 1974.

Lausz K., Metoda intuicyjna (intuitywna), metoda impresyjna, [w:] idem, Podstawowe problemy wspótczesnej metodyki literatury, Warszawa 1970.

Leśniewski N., Hermeneutyka przeżycia, „Teksty Drugie” 2007, nr 1/2.

Matuchniak-Krasuska A., Publiczność wobec metafory plastycznej. O recepcji groteski Jerzego Dudy-Gracza, Łódź 1999.

Mikeska-Kycia D., Zagadnienie intuicji w filozofii Romana Ingardena, Kraków 2014.

Mlodinow L., Nieświadomy mózg. Jak to, co dzieje się za progiem świadomości, wptywa na nasze życie, Warszawa 2016.

Myers D.G., Dwa rodzaje wiedzy, [w:] idem, Intuicja - jej sita i słabość, Taszów 2004.

Myrdzik B., Rola hermeneutyki w edukacji polonistycznej, Lublin 1999.

Neville B., Psyche i edukacja. Emocje, wyobraźnia i nieświadomość w uczeniu się i nauczaniu, Kraków 2009.

Okoń W., Podstawy wyksztatcenia ogólnego, Warszawa 1976.

Poletur B., Interpretacja lektury w szkole jako środek ksztatcenia intuicji bezpośredniego przeżycia i wyobraźni twórczej, „Ogniwo” 1924, nr 5/7, 8/9, 11, 12.

Rosińska Z., Tożsamość odbiorcy. Psychoanalityczne punkty widzenia, [w:] Twórczy odbiór sztuki, red. J. Brach-Czaina, Białystok 1992. 
Sobańska M., Apollo i Psyche w edukacji polonistycznej. W kręu badań nad umystem i intuicja, Poznań 2018 (praca magisterska napisana pod kierunkiem prof. Anety Grodeckiej).

Spitzer M., Jak uczy się mózg, Warszawa 2017.

Tatarkiewicz W., Przeżycie estetyczne, [w:] idem, Dzieje sześciu pojęć, Warszawa 1975.

Tatarkiewicz W., Skupienie i marzenie. Studia z zakresu estetyki, Kraków 1951.

Varela F., Neurofenomenologia. Metodologiczne lekarstwo na trudny problem, „Avant” 2010, nr 1 .

Wóycicki K., Rozbiór literacki w szkole: podręcznik dla nauczycieli, [w:] Teoria kształcenia literackiego w latach 1918-1939. Antologia, red. L. Jazownik, cz. 1, Zielona Góra 2001.

Zawistowska M., Szósty zmyst, [w:] Sensualność w kulturze polskiej, http://sensualnosc. bn.org.pl/pl/articles/szosty-zmysl-698 [dostęp: 28.09.2019].

Summary: The author is interested in the scope of modifying the way that Polish is taught at school by applying discoveries of social neuroscience. Referring to philosophy (Henri Bergson, Roman Ingarden, Francisco Varela), the latest discoveries in the field of neurology, the differences between emotional and practical experience of the text are considered. Earlier didactic approaches were also recalled (Kazimierz Wóycicki, Bronisław Poletur, Wincenty Okoń, Stanisław Bortnowski, Anna Janus-Sitarz) and the results of an experiment related to intuitive reception of Bolesław Leśmian's poem ${ }^{* * * *}$ Wyszło z boru ślepawe, zjesieniałe zmrocze... On this basis an idea of intuitive interpretation was outlined based on phenomenology, neuroscience and her own teaching expertise.

Keywords: Polish didactics; neuroscience; mind; intuition; interpretation 